\title{
Natural Selection Intensity among the Paki: An Endogamous Population of Andhra Pradesh
}

\author{
Ch. Nooka Raju, S. Amrutha Varshini and D.S.R.S. Prakash \\ Department of Biotechnology, Godavari Institute of Engineering \& Technology, Rajahmundry \\ 533 294, East Godavari District, Andhra Pradesh, India \\ E-mail : drdevaprakash@gmail.com
}

KEYWORDS Natural Selection Intensity. Mortality. Fertility. Caste. Andhra Pradesh

ABSTRACT The selection intensity indices were computed based on the demographic information pertaining to fertility and mortality among the Paki, an endogamous caste population of Andhra Pradesh. In the present population, the selection is manifested mainly through differential fertility rather than mortality. This situation may be due to changing socio-economic condition of these people.

\section{INTRODUCTION}

Darwin contemplated variation or the diversity among population as his starting point for considering the action of natural selection for the descent of the organisms with modifications which refers to evolution. He named the agent, by which selection operates "survival of the fittest", referring by the phrase to the differential mortality of individuals within a species. His concept has since been broadened to include the selection agent of differential fertility. It is probable that natural selection operating through differential mortality is less important among modern human populations where differential fertility appears to be the more effective agent (Cavalli-Sforza and Bodmer 1971). Based on this, Crow (1958) devised an index $\left(\mathrm{I}_{t}\right)$ of the opportunity for natural selection to quantify the influence of selection inherent in evolutionary process, which composed of two components - component of mortality prior to the reproductive age $\left(\mathrm{I}_{\mathrm{m}}\right)$ and component of fertility among women who have reached reproductive age $\left(\mathrm{I}_{\mathrm{f}}\right.$,). Since this index covers only the postnatal mortality, Johnston and Kensinger (1971) revised the computation by considering the prenatal mortality also. The present paper reports the intensity of selection in terms of Crow's as well as Johnston and Kensinger's indices among Paki caste population of Andhra Pradesh. Traditionally, Paki was a scavenger community and now it is categorized as a scheduled caste.

\section{METHODOLOGY}

The sample consisted of 100 families of
Paki caste living in Narsapuram mandal, West Godavari District, Andhra Pradesh. The data pertaining to fertility and mortality were obtained by interviewing married women using a schedule. The data on mortality covered deaths at both prenatal (abortions and still births) and postnatal stages (pre-reproductive deaths). The selection intensity indices were calculated by original formula of Crow (1958) and modified formula of Johnston and Kensinger (1971).

\section{RESULTS AND DISCUSSION}

The indices of intensity of selection and their components, based on the methods of Crow as well as Johnston and Kensinger are given in Table 1. The Crow's total index of natural selection is 0.7156 . The fertility and mortality components of Crow's index are 0.6589 and 0.0567 , respectively. While in Johnston and Kensinger's method, these

Table 1: Natural selection intensity among Paki caste population of Andhra Pradesh

\begin{tabular}{lc}
\hline Selection component & Value \\
\hline Crow's Index & \\
Mortality component $\left(\mathrm{I}_{\mathrm{m}}\right)$ & 0.0567 \\
Fertility component $\left(\mathrm{I}_{\mathrm{f}} / \mathrm{P}_{\mathrm{s}}\right)$ & 0.6589 \\
Total index $\left(\mathrm{I}_{\mathrm{t}}\right)$ & 0.7156 \\
\% of fertility component & 92.08 \\
\% of mortality component & 7.92 \\
Johnston and Kensinger's Index & \\
Prenatal mortality component $\left(\mathrm{I}_{\mathrm{me}}\right)$ & 0.0466 \\
Post natal mortality component $\left(\mathrm{I}_{\mathrm{mc}} / \mathrm{P}_{\mathrm{b}}\right)$ & 0.0567 \\
Fertility component $\left(\mathrm{I}_{\mathrm{f}} / \mathrm{P}_{\mathrm{b}} \cdot \mathrm{P}_{\mathrm{s}}\right)$ & 0.6589 \\
Total index $\left(\mathrm{I}_{\mathrm{t}}\right)$ & 0.7622 \\
$\%$ of fertility component & 86.45 \\
\% of prenatal mortality component & 6.11 \\
$\%$ of postnatal mortality component & 7.44 \\
\hline
\end{tabular}


values are 0.6589 and 0.1033 , respectively. The total index of Johnston and Kensinger' method is slightly higher than the index of Crow, due to additional contribution of prenatal mortality. The contribution of prenatal mortality to the total index is 0.0466. In this population, the fertility component is higher than the mortality component.

The indices of total selection as well as of fertility and mortality components of the present population are higher than majority of other caste populations of Andhra Pradesh (Babu et al. 1995; Dharani Priya et al. 2003). The averages of Andhra caste populations (Reddy and Chopra 1990) are also higher than the present values. Considering the proportion of fertility and mortality components to the total selection, the fertility component is higher than mortality component in the present community, though it belonged to low socio-economic stratum. It may be due to changing socio-economic situation of the people and better accessibility to the healthcare. However, it is important to mention that strict interpretation of these indices is difficult as the natural selection is effective only to the extent that these vital events are genetically determined. There are empirical evidences to the change of selection opportunities with changing environment over a period and to demonstrate the relevance of socio-economic change to the evolution of selective patterns (Terranato et al. 1979; Ulizzi et al. 1979).

\section{ACKNOWLEDGEMENTS}

Authors thank the community members of Paki for their cooperation during data collection.

\section{REFERENCES}

Babu BV, Kusuma YS, Naidu, JM 1995. Opportunity for natural selection among four Andhra caste populations. J Hum Ecol, 6: 63-64.

Cavalli-Sforza LL, Bodmer WF 1971. The Genetics of Human Populations. San Francisco: W.H. Freeman.

Crow JF 1958. Some possibilities of measuring selection intensity in man. Hum Biol, 30: 1-13.

Dharani Priya B, Veerraju P, Rao TV 2003. Selection intensity among Kshatriyas, an endogamous population of Andhra Pradesh. Indian J Hum Genet, 9: 69-73.

Johnston FE, Kensinger KM 1971. Fertility and mortality differentials and their implications for microevolutionary change among Cashinahua. Hum Biol, 43: 356-364.

Reddy BM, Chopra VP 1990. Opportunity for natural selection among Indian populations. Am J Phys Anthrop, 83: 281-296.

Terranato L, Ulizzi L, San Martini A 1979. The effect of demographic transition on the opportunity for selection: changes during the last century in Italy. Ann Hum Genet, 42: 391-399.

Ulizzi L, San Martini A, Terranato L 1979. Changes in selection opportunities with changing environment, regional heterogeneity in Italy. Ann Hum Genet, 43: $137-141$. 